\title{
Pemikiran Abdurrahman Wahid tentang Islam dan Humanisme
}

\author{
Puput Dwi Lestari \\ Program Magister Aqidah dan Filsafat Islam \\ UIN Sunan Kalijaga Yogyakarta \\ dwipuput82@yahoo.co.id
}

\begin{abstract}
In the Islamic world itself, the idea of humanism has been started since the beginning of Islamic history, namely when there was a debate between various schools of kalam about human destiny. The question that is often asked is whether humans have the freedom to determine their own destiny or humans have no free will at all, but their fate is determined by God. Abdurahman Wahid (Gus Dur) is one of the prominent Islamic figures who carries the idea of humanism. The enormous contribution of the ideas of Gus Dur's humanism, according to the author, is very important to study, this is because the ideas of Gus Dur's humanism are needed to understand Islam in relation to the problems of humanity and civilization. This is where the ideas of Gus Dur's humanism are believed to be able to answer the problems of the Indonesian people in relation to humanitarian issues, such as backwardness, poverty and ignorance. In order to synthesize between Islamic insights and Indonesian-Indonesian contexts, the writer tries to present a new breakthrough by examining Gus Dur's humanism ideas more. By using the Library Research method (literature review) the author tries to explain the idea of Gus Dur's humanism. This idea was obtained by the writer by reading and understanding various books by Gus Dur as primary data and several scientific journals as supporting data. The results of this paper stated that in Gus Dur's view, aspects of humanism were revealed in several important terms, firstly guaranteeing freedom of religion, secondly guaranteeing the protection of basic human rights, thirdly democratic culture, fourthly protecting minorities.
\end{abstract}

Keyword : Abdurrahman Wahid, Islam, humanism

\begin{abstract}
Abstrak: Dalam dunia Islam pemikiran mengenai humanisme telah dimulai sejak awal-awal sejarah Islam, yaitu ketika terjadi perdebatan antar berbagai aliran kalam mengenai nasib manusia. Pertanyaan yang sering diajukan adalah apakah manusia memiliki kebebasan untuk menentukan nasibnya sendiri atau manusia tidak memiliki kebebasan berkehendak sama sekali, tetapi nasibnya ditentukan oleh Tuhan. Abdurahman Wahid (Gus Dur) merupakan salah satu tokoh Islam yang gencar mengusung gagasan humanisme. Kontribusi yang sangat besar dari pemikiran humanisme Gus Dur menurut penulis sangat penting untuk dikaji, hal ini dikarenakan pemikiran humanisme Gus Dur diperlukan untuk memahami Islam dalam kaitannya dengan permasalahan kemanusiaan dan peradaban. Disinilah pemikiran humanisme Gus Dur di percaya akan mampu menjawab permasalahan bangsa Indonesia terakait dengan permasalahan kemanusiaan, seperti keterbelakangan, kemiskinan dan kebodohan. Dalam rangka mensintesakan antara wawasan keislaman dengan konteks keindonesiaan penulis berusaha untuk menyuguhkan terobosan baru dengan mengkaji lebih dalam gagasan humanisme Gus Dur. Dengan menggunakan metode Library Research
\end{abstract}




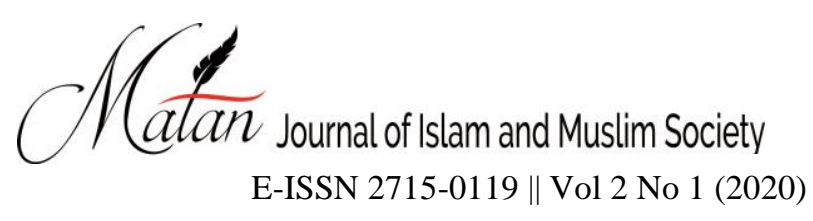

(kajian pustaka) penulis berusaha memaparkan gagasan humanisme Gus Dur. Gagasan ini penulis peroleh dengan cara membaca dan memahami berbagai buku karya Gus Dur sebagai data primer dan beberapa jurnal ilmiah sebagai data pendukung. Hasil dari tulisan ini menyatakan bahwa dalam pandangan Gus Dur, aspek humanisme diturunkan dalam beberapa term penting, pertama jaminan kebebasan dalam beragama, kedua jaminan adanya perlindungan hak-hak dasar kemanusiaan, ketiga budaya yang demokratis, keempat perlindungan terhadap kalangan minoritas.

Kata Kunci: Abdurrahman Wahid, Islam, humanisme

\section{A. Pendahuluan}

Secara geneologi istilah humanisme mulai populer menjelang berakhirnya zaman pertengahan hingga masa renaisans yaitu pada abad $14 \mathrm{M} .{ }^{1}$ Perubahan paradigma terjadi pada masa ini, pemikiran manusia mengalami perubahan yang sangat mendasar, pada awal mulanya perbincangan terpusat pada persoalan makrokosmos (alam semesta) berubah menjadi perbincangan mikrokosmos atau antroposentrisme (manusia). ${ }^{2}$ Humanisme sebagai suatu gerakan yang reaksioner muncul sebagai akibat dari adanya belenggu kekuasaan lembaga-lembaga agama di Eropa pada Abad pertengahan. ${ }^{3}$

Istilah humanisme muncul karena adanya belenggu kekuasaan pada lembaga-lembaga agama di Eropa pada Abad pertengahan. Kebudayaan Romawi dan Yunani Kuno memberikan inspirasi pada kebudayaan Eropa, sehingga humanisme dibutuhkan untuk meruntuhkan kebekuan gereja yang saat itu mengekang kreatifitas, cara tangkap dan kebebasan manusia di Eropa saat itu. Kekakuan gereja Eropa pada abad pertengahan inilah yang dianggap sebagai sitausi anti-humanis karena akal budi tidak diberikan kesempatan untuk digunakan oleh manusia sebagai potensi terbesar untuk mengatur kehidupannya.Maka agama, gereja, dan Tuhan pada akhirnya menjadi common enemy dari kaum humanis yang

\footnotetext{
${ }^{1}$ Harun Hadiwiyono, Sari Sejarah Filsafat Barat 2, (Yogyakarta: Kanisius, 1995), p. 11.

${ }^{2}$ Harun Hadiwiyono, Sari Sejarah Filsafat Barat 2, p. 15.

${ }^{3}$ Pada masa ini kebebasan manusia dan rasionalitasnya berada pada masa yang 'gelap'. Abad Kegelapan
} tersebut tergambar pada kondisi kematian daya nalar manusia yang ditandai dengan munculnya sekat-sekat pemisah antara ranah agama-spriritualitas dan ranah duniawi. Kehidupan Eropa di Abad Pertegahan berada pada wacana teologis yang hegemonis dengan model kekuasaan para pemimpin lembaga agama sangat doktriner dan otoriter. Adanya otoritas agamawan yang sangat absolute, menghambat perkembangan penemuan-penemuan para ilmuwan, dan teori-teori yang berseberangan dengan kekuatan dogma agama dianggap menyimpang dan sesat. Konsep rasionalisasi atas keyakinan dan pemahaman yang tidak sesuai dengan tradisi agama dianggap menyimpang atau melawan kekuatan Tuhan.

Gambaran kehidupan keagamaan yang mengesampingkan nilai-nilai kehidupan serta potensi rasionalitas manusia, kemudian mendorong para intelektual untuk bersikap kritis. Prinsip humanisme sebagai cita-cita untuk memanusiakan manusia sebagai usaha humanisasi. Apabila disejajarkan dengan cita-cita dalam konteks agama, sebenarnya adalah suatu bentuk cita-cita yang sama. Memahami agama dalam praktek para penganutnya sering menghadapi penyelewengan dan bahkan menimbulkan tragedi kemanusiaan. Hal ini menjadikan peran agama di era modern terus dipertanyakan. Tantangan terhadap menurunnya kepercayaan manusia terhadap agama semakin hebat pada akhir abad 20. Humanisme, sebagai paham pembanding dari agama dapat dijadikan sebagai dorongan positif untuk mengembalikan cita-cita humanisasi pada agama. Lihat Samasno Hadi, "Konsep Humanisme Yunani Kuno dan Perkembangannya Dalam Sejarah Pemikiran Filsafat", dalam Jurnal Filsafat, 2.2 (2012), p. 108. 
menginginkan runtuhnya agama demi tegaknya kemanusiaan. ${ }^{4}$ Gerakan ini terus berkembang dan menjadi dasar lahirnya gerakan Renaisans Eropa. Kemudian, dalam perkembangannya humanisme mengalami pasang surut pada abad ke-14 M di Italia pada saat sastra dan seni Romawi Yunani pra-Kristiani ditemukan kembali dan dijunjung tinggi oleh para Paus dengan dibangunnya museum-museum karya-karya sastra dan seni. ${ }^{5}$

Memasuki awal abad ke-15 M humanisme sudah mempengaruhi sampai pada lingkungan pendidikan formal di Eropa, khususnya di Italia. Melalui pandangan, pemikiran, serta dogma-dogma humanisme para kaum humanis kemudian masuk ke dalam lingkungan sekolah dan universitas. Menurut K. Bertens humanisme adalah istilah yang memiliki pemaknaan dan riwayat yang kompleks, di Jerman pengunaan kata humanisme pertama digunakan dalam literatur sekitar tahun $1806 \mathrm{M}$, sementara di Inggris digunakan pada tahun 1860. Sementara itu kata humanisme sebagai sebuah istilah mulai dikenal dalam wacana filsafat sekitar abad ke-19 M. ${ }^{6}$ Memasuki abad ke-20 M, para intelektualseperti, Jaquet Maritain, Bernand Muchlandm Boisard, Ali Syariati, serta Syed Vahiduddin, dan sebagainyamulai menyadari dalam pemisahan antara agama dan humanisme terdapat berbagai ketimpangan Mereka menyatakan bahwa agama dan humanisme bukanlah suatu tradisi yang harus dipisahkan dan menjadi dua halbertentangan. Karena antara humanisme dan agama merupakan dua hal yang saling mengisi dan melengkapi. ${ }^{7}$ Humanisme memiliki prinsip-prinsip mengenai hidup rukun antar penganut dan pemeluk berbagai agama, seperti halnya toleransi. Disini terlihat bahwa kaum humanis memegang teguh semangat persaudaraan sebagai suatu pandangan kolektif yang prinsipil dalam semua keyakinan agama. Pandangan tersebut memiliki tujuan terhadap perdamaian agama secara universal. ${ }^{8}$ Kesadaran akan Nilai-nilai kemanusiaan (dimensi humanistik) akhirnya dibangkitkan oleh gerakan humanisme.

Sifat alamiah dalam struktur manusia sebagai makhluk yang berasal dari alam merupakan hal yang tidak dapat diabaikan dan dipisahkan. Struktur alamiah ini melekat pada jasmani dan indera. Hal tersebut menurut kaum humanis merupakan konsekuensi logis dari pandangan naturalisme yang berarti bahwa manusia adalah bagian dari alam, dan alam itu sendiri merupakan habitat yang nyata bagi manusia. Jika pada abad ke-20 M, terjadi ketimpangan dalam pemisahan agama dan humanisme, maka abad ke-21 M, merupakan ajang pertempuran wacana antara fundamentalisme dan toleransi kosmopolitan. Pola pikir,

4 Syaiful Arif, Humanisme Gusdur: Pergumulan Islam dan Kemanusiaan, (Yogyakarta: Ar-Ruzz Media, 2013), p. 39-40.

5 Samasno Hadi, Konsep Humanisme Yunani Kuno dan Perkembangannya Dalam Sejarah Pemikiran Filsafat, p. 111.

${ }^{6}$ Mulyana, "Humanisme dan Tantangan Kehidupan Beragama", dalam Jurnal Agama dan Lintas Budaya, Volume 1, Nomor 1, 2016, 41.

${ }^{7}$ Pada awalnya humanisme memang tidak anti agama. Humanisme hanya ingin mengurangi peranan institusi gereja dan kerajaan yang begitu besar, sehingga manusia sebagai makhluk Tuhan kehilangan kebebasannya. Mulyana, Humanisme dan Tantangan Kehidupan Beragama, dalam Jurnal Agama dan Lintas Budaya, p. 47.

${ }^{8}$ Dimensi humanistik adalah cakupan kemanusiaan, yakni manusia sebagai makhluk individual dan personal, menusia sebagai makhluk yang berpengetahuan, serta manusia yang menyejarah dan membentuk dirinya serta membentuk dunia secara alamiah. Dimensi humanistik sebagai cakupan kemanusiaan secara langsung melekat pada pemikiran manusia, pada tindakan-tindakan manusia, pada suatu sistem sosial masyarakat yang menjadi wadah eksistensi manusia. Lihat Samasno Hadi, Konsep Humanisme Yunani Kuno dan Perkembangannya Dalam Sejarah Pemikiran Filsafat, p. 112. 
cara bertindak, dan pola hidup sehari-hari manusia selalu diwarnai dengan benturan antara harapan, kegelisahan dan kecemasan. Pemikiran dan cara hidup yang berbeda-beda diakibatkan oleh globalisasi informasi dan gambar-gambar yang secara rutin ditransmisikan keseluruh muka bumi. Kaum kosmopolitan menyambut baik dengan merangkul kompleksitas budaya, namun kaum fundamentalis ${ }^{9}$ menganggap sebagai ancaman yang mengganggu dan berbahaya. ${ }^{10}$

Berdasarkan kajian secara historis maupun etimologis, dapat dikatakan pokok-pokok permasalahan yang menjadi kajian utama humanisme. Antara lain pertama, pembelaan terhadap nilai-nilai dan kebebasan manusia, kedua, perhatian pada aspek-aspek naturalistik manusia, ketiga, spirit toleransi baik dalam konteks ideologi filsafat maupun agama, dan keempat diskusi keagamaan yang meliputi persoalan mengenai Tuhan. Sebagai kajian di bidang filsafat yang intens membicarakan dan berusaha meninggikan harkat dan martabat manusia, maka humanisme sangat relevan untuk dijadikan sebagai reaksi untuk mencari alternatif pemikiran dalam menghadapi gejala-gejala dehumanisasi dewasa ini.

Dalam Islam pemikiran mengenai humanisme telah dimulai sejak awal-awal sejarah Islam, yaitu ketika terjadi perdebatan antar berbagai aliran kalam mengenai nasib manusia. Pertanyaan yang sering diajukan adalah apakah manusia memiliki kebebasan untuk menentukan nasibnya sendiri atau manusia tidak memiliki kebebasan berkehendak sama sekali, tetapi nasibnya ditentukan oleh Tuhan. Kemudian, dalam perkembangannya perbincangan mengenai humanisme ini tidak begitu populer dalam Islam. Hal ini dikarenakan beberapa faktor antara lain; pertama, humanisme merupakan produk filsafat di mana sebagian besar umat muslim anti filsafat.

Kedua, otoritas yang dimiliki manusia untuk menentukan nasibnya sendiri secara bebas tanpa adanya intervensi kekuatan diluar dirinya, adalah hal yang diindikasikan oleh humanisme. Sementara pengertian Islam secara teks dimaknai sebagai ketundukan dan kepatuhan terhadap kekuatan yang berada diluar diri mausia, yaitu yang menentukan nasib manusia adalah Tuhan. Ketiga, Islamolog Barat (Orientalis) memahami Islam hanya melalui unsur-unsur eksoterik menyamakan Islam dengan terorisme, monarkhi, fanatisme, kedzaliman, dan sikap keprimitifannya. Dalam pendangan ini Islam dianggapsebagai agama yang tidak menghargai nilai-nilai kemanusiaan. ${ }^{11}$

Di antara tokoh Islam yang gencar mengusung gagasan humanisme adalah

${ }^{9}$ Gerakan fundamentalis initidak disetujui oleh Gus Dur, karena cenderung menggunakan kekerasan. Menurutnya semua tindakan menggunakan kekerasan dengan label agama merupakan bentuk dari pengingkaran dan pendangkalan terhadap agama sebagai jalan keselamatan serta akan mereduksi nilai-nilai humanisme yang universal dalam agama tersebut. Karena itu tidak ada alasan untuk mengembangkan permusuhan kepada kelompok agama lain. Lihat Abdurrahman Wahid, Dialog Agama dan Masalah Pendangkalan Agama, dalam Komaruddin Hidayat dan Ahmad Gaus, (Jakarta: Gramedia Pustaka Utama, 1998), p. 53.

${ }^{10}$ Sambho Bartolomeus, Humanisme dan Humaniora, ed. Bambang Sugiharto, 262-263.

${ }^{11}$ Dalam Islam ada pemahaman yang beraneka ragam, di antaranya adanya tradisi kritis yang terus menyuarakan keberpihakan pada isu-isu demokrasi, gender, pluralisme, dan HAM. Lihat Akbar S Ahmed, Membedah Islam, terj. Zulfahmi Andri (Bandung: Pustaka, 1990), 01, Lihat juga Charles Kurzman, "Pengantar: Islam Liberal dan Konteks Islamnya", dalam Charles Kursman (ed). Wacana Islam Liberal Memikikan Islam Kontemporer Tentang Isu-isu Global, terj. Bahrul Ulum dan Heri Junaidi (Jakarta: Paramadina, 2003), pp. xii-xiii. 
Abdurrahman Wahid (Gus Dur). ${ }^{12}$ Pandangan Gus Dur pertama,prinsip kemanusiaan dan ketuhanan telah melahirkan pemahaman yang kuat terhadap Islam, melalui prinsip ini dapat dipahami bahwa kemanusiaan bukan antitesis atas ketuhanan, namun kemanusiaan merupakan perintah langsung dari Tuhan melalui manusia sebagai wakil-Nya dimuka bumi. ${ }^{13}$ Kedua, Gus Dur terlihat humanisme sebagai pembela HAM universal. Pemanfaatan partikularisme kultural digunakan demi perjuangan HAM universal yang diterapkan melalui pendekatan structural. ${ }^{14}$ Beberapa term penting dari aspek humanisme dalam pandangan Gus Dur, antara lain pertama jaminan kebebasan dalam beragama, kedua jaminan adanya perlindungan akan hak-hak dasar kemanusiaan, ketiga budaya yang demokratis, keempat perlindungan terhadap kalangan minoritas. Dari penggalian humanisme dalam pemikiran Gus Dur menjadi penting untuk melihat prinsip dasar dari segenap pemikiran dan gerakannya, mulai dari gerakan sosial hingga politik praktis. Gus Dus memang bukan pemikir humanisme dalam artian formal. Sebab, Gus Dur tidak secara khusus menulis tentang humanisme. Secara eksplisit tulisan Gus Dur yang berjudul humanisme hanya ada di buku Imam Khalil al-Farahidi dan Humanisme dalam Islam ${ }^{15}$ dan Mencari Prespektif Baru Hak Asasi Manusia. ${ }^{16}$

Humanisme yang digagas oleh Gus Dur di landasi dengan paradigma berpikirbersifat indedpenden, liberal, dan moderat yang akan memberikan nilai-nilai tersendiri bagi masyarakat. ${ }^{17}$ Pendekatan yang bersifat legalistik-formalistik, skripturalistik atau alternatif pandangan dunia (worldview) oleh Gus Dur dianggap tidak dapat diharapkan untuk menyelesaikan masalah kemiskinan, inilah pendekatan yang ditolak oleh Gus Dur. Menurutnya, kemiskinan hanya dapat diatasi melalui jalan mengembangkan lembaga kemasyarakatan secara adil, berupaya menegakkan demokrasi secara murni, serta menolak

\footnotetext{
${ }^{12}$ Gus Dur menyebut humanisme menggunakan istilah humanitarianisme. Penyebutan ini dimaksudkan untuk membicarakan dan apresiasi terhadap segala hal yang baik dalam manusia ditambah dengan perhatian dan kesejahteraan setiap individu. Ketertundukan dan takhzim kepada Tuhan merupakan asas paling tinggi dalam ideologi humanitarianisme. Greg Barton, Gagasan Islam Liberal di Indonesia: Pemikiran NeoModernisme Nurcholish Madjid, Djohan Effendim Ahmad Wahid dan Abdurrahman Wahid, (Jakarta: Paramadina-Pustaka Antara, 1999), p. 407.

${ }^{13}$ Syaiful Arif, Humanisme Gusdur: Pergumulan Islam dan Kemanusiaan, p. 55.

${ }^{14}$ Pendekatan structural merupakan pendekatan kritis atas ketimpangan struktural yang memberangus pemenuhan HAM universal. Gus Dur berusaha tidak terjebak dalam perdebatan universalisme dan partikularisme HAM. Ia menjalani semua itudalam perjuangan jangka panjang untuk menegakkan struktur masyarakat yang berkeadilan sebagai wujud praksis kemanusiaan.

${ }^{15}$ Dalam tulisan pertama Gus Dur lebih banyak mengeksplorasi sumbangan al-Farahidi, seorang ahli bahasa abad ke-2 $\mathrm{H}$ yang telah menyumbangkan tradisi humanistik di dalam Islam. Pemikiran humanisme Islam Gus Dur dimaknai sebagai rasionalisasi dan modernisasi Islam, sebab melaluinya Islam bisa diikutsertakan dalam pengembangan kemanusiaan secara umum. Pada titik ini, humanisme telah inheren dalam modernitas sehingga Islam keterlibatandalam modernisasi yang secara otomatis menggerakkan humanisme berbasis Islam.Lihat Syaiful Arif, Humanisme Gusdur: Pergumulan Islam dan Kemanusiaan, p. 56.

${ }^{16}$ Dalam tulisan kedua Gus Dur banyak berbicara berbagai perspektif tentang HAM. Gus Dus mengapresiasi pendekatan liberal yang berupaya memenuhi hak-hak sipil dan politik dari warga negara modern. Saat bersamaan pula Dus Dur mengusulkan penyempurnaan melalui apa yang ia sebut sebagai pendekatan struktural atas HAM. Pendekatan iniberupaya untuk memenuhi hak sosial ekonomi yang harus disediakan negara sehingga HAM belum terwujud ketika waga negara hanya diberi kebebasan politik, tetapi belum terpenuhi hak-hak dasar hidupnya sebagai manusia yang butuh hidup secara layak. Lihat Syaiful Arif, Humanisme Gusdur: Pergumulan Islam dan Kemanusiaan, p. 56.

${ }^{17}$ Alvian Muhammad dan Helmi Jacob (ed), Gus Dur Bertutur, (Jakarta: Divisi Penerbit Harian Proaksi, 2005), p. xxiv.
} 
ketidakadian disemua bidang dan jalan terakhir adalah melalui upaya mempersepsikan ulang iman, sehingga masalah kemiskinan dapat dipecahkan secara adil. ${ }^{18}$

Harus diakui dalam konteks ini Gus Dur tidak pernah menuliskan gagasan humanisme secara formal dalam suatu karya, akantetapi ia menyelipkan prespektif humanistik dalam lapisan-lapisan terdalam dalam pemikirannya. Hal ini terjadi karena Gus Dur membungkus gagasan humanismenya di dalam tema-tema seperti kesejahteraan rakyat, keadilan, persamaan di depan hukum, demokrasi, hingga toleransi beragama. Kontribusi yang sangat besar dari pemikiran humanisme Gus Dur menurut penulis sangat penting untuk dikaji, hal ini dikarenakan pemikiran humanisme Gus Dur diperlukan untuk memahami Islam dalam kaitannya dengan permasalahan kemanusiaan dan peradaban. Disinilah pemikiran humanisme Gus Dur dipercaya akan mampu menjawab permasalahan terkait dengan masalah kemanusiaan, seperti keterbelakangan, kemiskinan dan kebodohan. Dalam rangka mensintesakan antara wawasan keislaman dengan konteks keindonesiaan penulis berusaha untuk menyuguhkan terobosan baru dengan mengkaji lebih dalam gagasan humanisme Gus Dur.

\section{B. Biografi Abdurrahman Wahid}

Abdurrahman Wahid atau akrab disapa Gus Dur ${ }^{19}$ nama lengkapnya adalah Abdurrahman ad-Dakhil ${ }^{20}$ lahir di Jombang, Jawa Timur pada 7 September 1940, namun yang tercatat secara formal beliau lahir pada tanggal 4 Agustus $1940,{ }^{21}$ dan meninggal di usia 69 tahun pada 30 Desember 2009 di Jakarta. Beliau adalah anak pertama dari enam bersaudara, ayahnya bernama KH. Abdul Wahid merupakan putra dari tokoh terkenal KH. Hasyim Asy'ary, pendiri pondok pesantren Tebuirengdan pendiri Nahdhatul Ulama (NU) sebuah organisasi terbesar di Indonesia, serta merupakan seorang yang selalu bergulat dengan gerakan nasionalis, dan pernah menjadi mentri agama RI pertama dan aktif dalam Panitia Sembilan yang merumuskan Piagam Jakarta. ${ }^{22}$ Ibunya bernama Solehah, merupakan putri tokoh besar NU KH Bisri Syamsuri, pendiri pondok pesantren Denanyar Jombang.

Sang Kakek merupakan guru mengaji Gus Dur semasa kecil, pada sang kakeklah Gus Dur pertama kali belajar mengaji dan membaca al-Quran. Gus Dur dan keenam adiknya tidak pernah sekolah di lembaga pendidikan elit, dan tidak pernah bersekolah di sekolah

18 Syaiful Arif, Humanisme Gusdur: Pergumulan Islam dan Kemanusiaan, p. 57.

${ }^{19}$ Selanjutnya penulis akan menggunakan Gus Dur dalam tulisan ini. Gus merupakan kependekan dari bagus, sebutan untuk anak seorang kiai di Jawa Timur dan Jawa Tengah.

${ }^{20}$ Dalam bahasa Indonesia Abdurrahman al-Dakhil berarti "hamba Allah, sang penakluk, yang ambil dari nama Abdurrahman al-Dakhil, seorang memegang kekuasaan pertama Islam di Spanyol selama 32 tahun sekitar 756-788 M. ia adalah seorang pelarian yang menyebrangi dataran tandus dan bukit batu, memasuki negeri sebagai orang asing yang tersisih. Namun berhasil membangun kekuasaan, kemakmuran negeri, menyusun tentara dan mengatur pemerintahan. Lihat Tim INCRes, Beyond The Symbols: Jejak Antropologis Pemikiran dan Gerakan Gus Dur, (Bandung: Remaja Rosdakarya, 2000), p. 26.

${ }^{21}$ Perbedaan tersebut terjadi karena ada pemahaman berbeda terhadap ungkapan hari keempat bulan delapan. Tentu tidak salah jika kalimat "hari keempat bulan delapan" dipahami sebagai tangal 4 Agustus, tetapi dalam proses pencatatan itu kurang cermat memahami konteks kalimat tersebut, karena penyebutannya tidak merujuk pada penanggalan Masehi, tetapi merujuk pada kalender Arab yaitu 4 Sya'ban 1359 H atau tanggal 7 September 1940.Lihat Ahmad Salehudin, Abdurrahman Wahid: Keislaman, Kemanusiaan dan Kebangsaan, (Yogyakarta: Basabasi, 2019), p. 71.

${ }^{22}$ Umaradi Masdar, Membaca Pikiran Gusdur dan Amien Rais Tentang Demokrasi, (Yogyakarta: Pustaka Pelajar, 1998), p. 119. 
pendidikan agama, Gus Dur dan keenam adiknya masuk Sekolah Rakyat (SR) sebuah sekolah bentukan pemerintah Hindia Belanda untuk anak pribumi atau SDKRIS. Setelah lulus dari SR ia lalu melanjutkan pendidikan ke SMEP (Sekolah Menengah Ekonomi Pertama). ${ }^{23}$ Lulus dari SMEP Gus Dur lalu pindah ke Yogyakarta dan tinggal di rumah seorang anggota Majlis Tarjih Muhammadiyah, KH. Junaidi. Kegiatan Gus Dur di Yogyakarta sehari-harinya belajar di Pondok Pesantren Krapyak, pada pagi hari bersekolah di SMEP dan kegiatan pada siang dan malam hari adalah ikut berdiskusi dengan $\mathrm{H}$. Junaidi... ${ }^{24}$

Lulus dari SMEP, Gus Dur kemudian menghabiskan waktu dengan belajar di berbagai pesantren di Jawa. Pada tahun 1957-1959 ia mondok di Tegal Rejo, Magelang. Gus Dur hanya membutuhkan waktu dua tahun untuk belajar di pesantren tersebut, karena kesungguhan dan kemampuannya dalam bidang ilmu keislaman. Selain belajar ilmu-ilmu Islam, Gus Dur banyak menghabiskan waktu untuk membaca buku-buku filsafat karangan tokoh terkemuka seperti Karl Marx, Lenin Bramsci, Mao Zedong, serta karya pemikir Islam kiri seperti Hasan Hanafi. Selesai menimba pendidikan di pondok pesantren Tegal Rejo, Magelang, Gus Dur kemudian melanjutkan pendidikan di Muallimat Bahrul Ulum, Tambak Beras, Jombang, Jaw Timur pada tahun 1959-1963. Selanjutnya berangkat ke Mesir dan belajar di Universitas al-Azhar, Kairo pada tahun 1964-1966. Karena menganggap sistem pengajaran di Al-Azhar sudah usang Gus Dur justru banyak mengahbiskan waktu untuk menonton film Perancis, Inggris dan Amerika, serta membaca buku di perpustakaan. ${ }^{25}$

Beliau kemudian meninggalkan Kairo pada tahun 1966-1970 karena tidak puas dengan sistem pembelajaran di Al-Azhar dan melanjutkan studi di Departement of Religion spesialisasi sastra dan ilmu kebudayaan Arab, Universitas Baghdad. Saat di Universitas ini ia merasa puas dan telah menemukan panggilan jiwanya yang modernis. Selama di Universitas Baghdad Gus Dur banyakmemperoleh informasi sejarah lengkap tentang Indonesia serta mengenal karya-karya tokoh terkenal seperti Emil Durkheim. Melalui ihya 'Ulum ad Din karya Imam al-Ghazali pemikiran Gus Dur banyak dipengaruhi dan mampu mengembangkan intuisinya yang begitu jauh. ${ }^{26}$

Gus Dur tampil menjadi seorang muslim modernis setelah membaca karya-karya sastra dan budaya Arab serta filsafat dan pemikiran sosial Eropa. Ia mulai mengajukan gagasan tentang perlunya penafsiran kembali ajaran Islam, serta mengubah pendidikan dan pengajaran Islam yang sesuai dengan tantangan zaman, perkembangan ilmu pengetahuan dan teknologi. ${ }^{27}$ Selesai menempuh pendidikan di Timur Tengah, pendidikan doktormya ia tempuh di Eropa. Namun, ia lebih banyak belajar bahasa Perancis, Jerman dan Inggris karena keterbatasannya pada bahasa Eropa, Gus Dur kemudian tidak mampu menyelesaikn pendidikan doktornya. Gus Dur lalu kembali ke Indonesia, dan kembali ke Pondok Pesantren Tebuireng, Jombang. Bekal kemampuan ilmu agama Islam dan keilmuan lainnya, Gus Dur kemudian mejadi jurnalistik serta cendikiawan Muslim yang berjiwa sosial demokrat dan

${ }^{23}$ Ali Yahya, Sama tapi Berbeda, Potret Keluarga Besar KH. Wahid Hasyim, (Jombang: Pustaka Ikapete the Ahmadi Institut, 2007), p. 166.

24 Ahmad Salehudin, Abdurrahman Wahid: Keislaman, Kemanusiaan dan Kebangsaan, p. 74.

25 Ahmad Salehudin, Abdurrahman Wahid: Keislaman, Kemanusiaan dan Kebangsaan, 77

26 Ahmad Salehudin, Abdurrahman Wahid: Keislaman, Kemanusiaan dan Kebangsaan, 79.

27 Ahmad Salehudin, Abdurrahman Wahid: Keislaman, Kemanusiaan dan Kebangsaan, 78. 
progresif. Kemudian ia menjadi dosen Fakultas Ushuluddin Universitas Hasyim Asy'ary pada tahun 1972-1974, dilanjutkan dari tahun 1974 sampai 1980 ia menjadi sekertaris umum Pesantren Tebuireng. ${ }^{28}$

Sebagai seorang tokoh politik, agamawan, negarawan, dan guru bangsa pemikiranpemikran Gus Dur banyak dicurahkan melalui karya ilmiah baik dalam bentuk artikel maupun dalam bentuk buku. Sehingga tergolong sebagai penulis yang produktif, khususnya tentang dunia pesantren. Di antara karya tulisannya antara lain Islamku Islam Anda Islam Kita, Tuhan Tidak Perlu Dibela, Gus Dur dan Sepakbola: Kumpulan Kolom Gus Dur Tentang Sepakbola, Umat Bertanya Gus Dur Menjawab, Sekadar Mendahului, Khazanah Kiai Bisri Syansuri, Kiai Nyentrik Membela Pemerintah, Membaca Sejarah Nusantara: Dua Puluh Lima Kolom Sejarah Gus Dur, Dialog Peradaban Untuk Toleransi, Islam Kosmopolitan, dan sebagainya.

\section{Pemikiran Islam dan Humanisme Abdurrahman Wahid}

Humanisme secara harfiah memiliki akar kata "humus" yang berarti tanah atau bumi. Dari kata tersebut kemudian muncul istilah "homo" yang berarti manusia dan "humanus" yang berarti manusiawi, serta "humilis" yang berarti kesederhanaan atau kerendahan hati. ${ }^{29}$ Paham yang dianut oleh humanisme adalah menempatkan manusia sebagai pusat realitas. Manusia sebagai pusat realitas mempunyai fungsi ganda yakni sebagai subyek pengolah alam sekaligus sebagai objek tujuan dari pengolahan alam tersebut. ${ }^{30}$

Penandasan tulisan ini pertama penulis mulai dengan pandangan ontologis Gus Dur atas manusia, dimana pandangan tersebut berada di dalam domain keislaman. Prinsip humanisme Islam yang digagas Gus Dur disebut sebagai universalisme Islam. Corak Hak Asai Manusia (HAM) yang pilih berada pada titik keseimbangan antara pendekatan liberal yuridis-politis dengan pendekatan struktural sosio-ekonomi. Dengan demikian, dapat dikatakan bahwa HAM Gus Dur ingin menyeimbangkan antara pemenuhan hak sosialekonomi dengan hak-hak sipil. Kedua, humanisme di dalam pemikiran Gus Dur dibagi menjadi dua prinsip yaitu prinsip kesatuan pemikiran Islam dan prinsip kesatuan kebudayaan. ${ }^{31}$

Kesatuan pemikiran Islam merupakan jalinan struktural antara Islam sebagai etika, dan negara kesejahteraan Islam dengan pribumisasi Islam. Sementara kesatuan kebudayaan merupakan kesatuan pemkiran sosial budaya, demokrasi, dan ke NU-an. Dialektika ini dalam pandangan Gus Dur harus berjalan dengan tidak dapat dinilai secara hitam putih atau salah-benar, sebab proses pemaknaan akan terus berjalan. ${ }^{32}$ Di dalam prinsip ini kebudayaan sebagai kehidupan sosial manusiawi menjadi dasar bagi demokrasi sebagai proses serta peran kebangsaan NU yang menggambarkan komitmen Gus Dur atas perjuangan kemanusiaan dalam bentuk penegakan keadilan sosial. ${ }^{33}$

${ }^{28}$ Tim INCRES, Beyond the Simbol: Jejak Antropologis Pemikiran dan Gerakan Gus Dur, (Bandung: Remaja Rosdakarya., 2000), pp. 19-20.

${ }^{29}$ Tony Davies, Humanism, (New York: Roudledge, 1997), pp. 125-126.

30 Syaiful Arif, Humanisme Gusdur: Pergumulan Islam dan Kemanusiaan, p. 39.

31 Syaiful Arif, Humanisme Gusdur: Pergumulan Islam dan Kemanusiaan, 38.

${ }^{32}$ Ellyasa K.H. Darwis, Gus Dur dan Masyarakat Sipil (Yogyakarata: LkiS, 1994), p. 9.

${ }^{33}$ Greg Barton, Biografi Gus Dur, terj. Lie Hua, cetakan ke-VII, (Yogyakarta: LKiS, 2008), p. 8. 
Dasar keprihatinan yang menggerakkan Gus Dur untuk berpikir dan bertindak adalah adanya struktur masyarakat yang timpang membuat manusia terhambat memenuhi kebutuhannya. Dari sinilah dasar dari segenap pemikiran humanisme Gus Dur. ${ }^{34}$ Dalam konteks ini, Gus Dur memaknai humanisme sebagai upaya pemuliaan atas martabat manusia yang tinggi, dihadapan Tuhan. Asumsi dasar atas manusia ini menurut Gus Dur terdapat pada pesan-pesan yang dibawa Islam pada umat manusia, meliputi perintah untuk bertauhid, melaksanakan syariah dan menegakkan kesejahteraan di dunia.

Manusia dengan keseluruhan peranan status dan bentuk kemakhlukannya kemudian dijadikan sebagai pengganti-Nya di muka bumi, dengan demikian Allah telah memberikan contoh yang sempurna yaitu Nabi Muhammad saw. Hal tersebut dinyatakan dalam al-Quran laqad kaana lakum fi rasulillah uswatun hasanah (telah ada bagi kalian keteladanan sempurna dalam diri Rasulullah). Keteladanan Rasulullah tersebut terwujud dalam peranan nabi membawakan kesejahteraan bagi seluruh umat manusia (rahmatan lil alamin). Karena meneladani keteladanan nabi ituah manusia diberi status tinggi dihadapan Allah swt. seperti sabda-Nya Walaqad karrama bani adam (sungguh telah Ku-muliakan anak Adam). Kemudian dilengkapi lagi dengan firman-Nya Laqad qalaqnal insana fi ahsani taqwim (sesungguhnya telah Ku-jadikan manusia dalam bentuk kemakhlukan yang sebaikbaiknya). ${ }^{35}$

Agama sebagai keyakinan, ketiga dasar diatas bermuara pada bertauhid, bersyariat, dan mengupayakan kesejahteraan manusia menunjukan dasar humanisme. Artinya bagi Gus Dur pemuliaan dan upaya menyejahterakan manusia dilakukan Gus Dur setelah bertauhid dan bersyariat. ${ }^{36}$ Titik tolak intelektual Gus Dur berada pada pendasaran kemanusiaan dari ajaran Islam atau penemuan ajaran kemanusiaan di dalam Islam. Hal ini disampaikan pada pernyataannya mengenai penyebutan "yang paling universal" di dalam Islam.

Bagi Gus Dur universalisme Islam telah menampakkan diri dalam berbagai manifestasi penting dalam rangkaian ajaran yang meliputi berbagai bidang seperti keimanan (tauhid), etika (akhlaq), hukum agama (fiqh), dan sikap hidup yang menampilkan kepedulian terhadap unsur-unsur utama dari kemanusiaan (al-insaniyyah). Prinsip utama dari kemanusiaan meliputi persamaan derajat dimuka hukum, penjagaan hak-hak warga negara atas wewenang para pemegang kekuasaan, dan perlindungan hak-hak warga negara dari kelaliman dan kesewenang-wenangan. Sedangkan terdapat lima buah jaminan dasar dari agama samawi yang menampilkan universalisme Islam secara sempurna yang terdapat

\footnotetext{
${ }^{34}$ Prinsip kemanusiaan salah satunya ia temukan dalam buku Etika Necomechea karya Aristoteles. Buku yang ia baca ketika di Mesir inilah yang menyelamatkannya dari pemahaman fundamentalisik atas Islam. Buku tersebut menjelaskan etika di dalam filsafat Aristotelian yang merujuk pada etika Eudaimonisme, yakni ajaran etika Aristotelian yang mengajarkan prinsip etika sebagai jalan bagi penciptaan kebahagiaan. Artinya yang etia atau baik yang dapat mengarahkan manusia mencapai kebahagiaan. Terdapat dua hal dalam kebahagiaan, pertama cara hidup kontemplatif, kedua politik yang merupakan ciri khas manusia. Lihat Aristoteles, Nicomachean Ethics, Sebuah Kitab Suci Etika, Terj. Embun Kenyowati, (Jakarta: Teraju, 2004), pp. 1-25.

${ }^{35}$ Abdurrahman Wahid, Pergulatan Negara, Agama dan Kebudayaan, (Depok: Desantara, 2001), p. 153.

${ }^{36}$ Abdurrahman Wahid memaknai rahmah tidak hanya sebagai kasih sayang, tetapi juga berarti kesejahteraan. Kemudian untuk meneladani peran rahmatan lil alamin inilah manusia menjadi makhluk yang dimuliakan oleh Allah, baik dalam bentuk kesempurnaan kemakhlukan maupun dalam tugas mulia yang diberikan Allah sebagai khalifatullah fi al-ard. Lihat Syaiful Arif, Humanisme Gusdur: Pergumulan Islam dan Kemanusiaan, p. 282.
} 
dalam literatur hukum agama (al-kutub al-fiqhiyyah), antara lain : keselamatan keyakinan beragama masing-masing pemeluk tanpa ada paksaan untuk berpindah agama, keselamatan fisik masyarakat dari tindakan kekerasan fisik diluar ketentuan hukum, keselamatan harta benda dan milik pribadi diluar prosedur hukum, keselamatan keluarga dan keurunan, dan keselamatan profesi. ${ }^{37}$

Terlihat bahwa universalisme Islam telah ditemukan Gus Dur dalam ajaran kemanusiaan. Artinya segenap nilai utama yang meliputi tauhid, fiqh, dan akhlaq menunjukkan kepedulian mendalam atas nasib kemanusiaan. Pada titik ini hal yang paling menarik adalah kemanusiaan yang ditempatkan sebagai universalisme Islam, hal ini menarik karena Gus Dur tidak menempatkan Allah atau tauhid sebagai universalisme Islam, hal tersebut dapat dipahami dalam kerangka pemahaman Gus Dur atas kemanusiaan sebagai perintah utama Tuhan. Ketika wujud dari kemanusiaan adalah perlindungan atas hak-hak dasar manusia, maka bentuk pelaksaan perlindungan tersebut adalah berada pada cara manusia mengutamakan hal-hal yang mengagungkan atau meninggikan martabat manusia. Manifestasi dari bentuk perlindungan tersebut adalah dengan memelihara hak asasi manusi manusia, dan mengembangkan struktur masyarakat muslim yang adil. Manifestasi ini berperan sebagai kuasi norma (bukan norma tetapi perannya seperti norma). Jika perkembangan zaman, kebudayaan dan agama tidak sesuai dengan ukuran diatas maka harus dihentikan. ${ }^{38}$

Ketika terjadi ketegangan antara agama dan kebudayaan menurut Gus Dur yang harus didahulukan adalah kemanusiaan. Gus Dur menempatkan kemanusiaan diatas ajaran agama yang bertentangan dengan kemanusiaan. Hal tersebut terdapat dalam kalimat terakhir yang menunjukkan rekomendasinya untuk menjadikan nilai kemanusiaan sebagai rem etis bagi ajaran agama yang memberangus kemanusiaan. ${ }^{39}$

Dalam penjelasan diatas juga menunjukkan manifestasi dari nilai kemanusiaan, yang menurutnya terdapat di dalam dua hal. Pertama, perlindungan atas hak asasi manusia. Dan kedua, pengembangan struktur masyarakat yang adil. Watak kemanusiaan terlihat dalam rumusan Gus Dur atas bentuk ideal dari Hak Asasi Manusia. Menurut Gus Dur kebutuhan nyata masyarakat dalam negara-negara berkembang adalah penemuan identitas diri melalui serangkaian upaya sosial ekonomis untuk meningkatkan kualitas hidup mereka sendiri. Harapan masyarakat kelas bawah terletak pada dukungan kelas atas kepada kelas bawah untuk mengembangkan diri dan menumbuhkan kekuatan mereka. Karena, perjuangan hakhak asasi masyarakat baru ada arti pentingnya apabila didukung oleh penguasa atau negara. Negara dapat melakukan perlindungan kepada rakyatnya dengan cara mengaitkan pendekatan liberal dibidang hak-hak yuridis dan politis dengan pendekatan struktural untuk menjamin persamaan kesempatan yang lebih adil bagi seluruh warga masyarakat, hal ini akan membawakan prespektif baru dalam upaya memperjuangkan hak-hak asasi manusia secara lebih matang. ${ }^{40}$

\footnotetext{
${ }^{37}$ Abdurrahman Wahid, Universalisme Islam dan Kosmopolitan Peradaban Islam, pelita, 1988, pp. 179-180.

38 Abdurrahman Wahid, Pergulatan Negara, Agama dan Kebudayaan, (Depok: Desantara, 2001), p. 89.

39 Syaiful Arif, Humanisme Gusdur: Pergumulan Islam dan Kemanusiaan, p. 287.

${ }^{40}$ Abdurrahman Wahid, Prisma Pemikiran Gus Dur, (Yogyakarta: LkiS, 2010), p. 90-100.
} 
Dari penjelasan diatas kita bisa membaca corak hak asasi manusia Gus Dur mengacu pada keseimbangan antara pendekatan liberal dan pendekatan struktural. Pendekatan liberal merujuk pada pemberian hak-hak yuridis politis yang akhirnya melahirkan hak sipil dan politik. Dalam prespektif HAM ini merupakan generasi pertama, hak tersebut mencakup hak kebebasan beragama dan kepercayaan, hak hidup, hak mengemukakan pendapat, dan hak untuk turut serta dalam pengambilan keputusan bersama, dalam UUD 1945 terkandung dalam pasal 27 (pasal 1), 28, dan 29.

Gus Dur kemudian menawarkan pendekatan struktural yang merupakan bagian dari generasi kedua dan ketiga dalam HAM. Generasi kedua ini terkait dengan proses kenegaraan yang memungkinkan terciptanya kehidupan yang semakin manusiawi, yang termasuk dalam hak ini adalah hak atas pekerjaan, hak atas pendidikan, hak layanan kesehatan, dan hak atas jaminan sosial, dalam UUD 1945 terkandung dalam pasal 27 (pasal 2), 31 dan 34. ${ }^{41}$ Sementara pengakuan akan perlindungan keseluruhan kehidupan manusia, baik sekarang maupun yang akan datang, baik di satu komunitas maupun antar komunitas, yang meliputi hak matas perlindungan lingkungan, hak masyarakat adat, hak ekonomi dan pembangunan, hak penentuan nasib sendiri, dan sebagainya, dalam UUD 1945 terkandung dalam pasal 30, 32, 33 (3), dan 34, merupakan generasi ketiga HAM. ${ }^{42}$

Dengan menciptakan keseimbangan antara generasi pertama prespektif liberal atas HAM dan generasi kedua prespektif struktural atas HAM, Gus Dur menyempurnakan perjuangan HAM kepada perlindungan atas keseluruhan hidup manusia yang merupakan generasi ketiga HAM.Pandangan ini oleh Gus Dur dinyatakan dalam bukunya Islamku, Islam Anda, Islam Kita. Di dalam buku tersebut disebutkan bahwa di hadapan masyarakat hanya ada satu dari dua kemungkinan: menolak Deklarasi Universal HAM itu sebagai sesuatu yang asing bagi Islam, seperti yang dilakukan al-Maududi terhadap Nasionalisme atau justru merubah diktum fiqh/hukum Islam itu sendiri. Sikap seperti ini menurut Gus Dur, hanya akan berarti menyakiti diri sendiri dalam jangka panjang. ${ }^{43}$

Dari sini dapat diambil kesimpulan bahwa humanisme yang diwacanakan bukan humanisme liberal, melainkan humanisme komunitarian. ${ }^{44}$ Pendasaran humanisme dari tradisi Islam ini sangat menonjol dalam pemikiran Gus Dur, karena wujud kecintaan kepada sesama manusia dapat terwujud apabila manusia sudah mulai menyadari keyakinan tauhid dan ketaatan kepada syari'at. Sebelum mencapai kesadaran ini manusia pada mulanya baru

\footnotetext{
${ }^{41}$ Gus Durmenyebut pendekatan striutural masuk ke dalam generasi kedua HAM ini, dimana negara wajib memberikan kesempatan yang sama agar warga masyarakat bisa mengembangkan diri secara setara. Jika generasi pertama HAM memiliki concern dengan kebebasan (liberty), dan pusat kebebasan itu berada dalam diri per individu manusia. Di gebenari kedua HAM fokus pada upaya pembebasan (liberation) melalui pembukaan kran-kran kesempatan agar warga negara bisa mengembangkan diri. Pusat pembebasan ini bukan individualisme melainkan kolektivitas yang terumuskan dalam tema warga negara yang lemah. Lihat dalam Syaiful Arif, Humanisme Gusdur: Pergumulan Islam dan Kemanusiaan, p. 290.

42 Yudi Latif, Negara Paripurna, Historisitas, Rasionalita dan Aktualisasi Pancasila, (Jakarta: Gramedia, 2011), pp. 192-193.

${ }^{43}$ Wahid, Abdurrahman, Islamku, Islam Anda, Islam Kita: Agama Masyarakat Negara Demokrasi, (Jakarta: the Wahid Institut, 2006), p. 122.

${ }^{44}$ Komunitarianisme menempatkan manusia tidak hanya sebagai individu abstrak yang lepas dari konteks kultural dimana manusia itu lahir, sementara liberalisme menempatkan individu sebagai pusat realitas sehingga masyarakat merupakan dampak dari kontrak sosial yang dibuat oleh individu demi pemenuhan kepentingan per individu.
} 
beriman saja, kemudian ia melaksanakan Islam ketika telah menyadari pentingnya syariat. Barulah manusia tersebut mencapai tingkat yang lebih tinggi lagi (ihsan) dengan mendalami tasawuf, hakikat dan ma'rifat. ${ }^{45}$

Humanisme ditemukan dan dialami ketika seseorang telah berada pada puncak keislaman yakni ihsan. Dalam tataran hakikat dan makrifat (ihsan) inilah seorang Muslim menemukan pengalaman tauhid atau syariat di dalam kecintaannya kepada sesama manusia. Humanisme tidak dapat ditemukan hanya di dalam tahapan iman dan Islam saja, karena itu seorang Muslim dapat menemukan kecintaan terhadap sesama manusia secara mendalam ketika Muslim telah berada di puncak tertinggi yaitu ihsan. ${ }^{46}$

Pemahaman humanisme sebagai perluasan pengetahuan Islam ke ranah global inilah yang disebut Gus Dur sebagai kosmopolitanisme Islam yang merupakan prasyarat paradigmatis dari universalisme Islam. Pada satu titik perluasan wawasan Islam ini merupakan konsekuensi logis dari muslim yang sadar akan perjuangan humanitarian. Konsekuensi ini terdapat pada perlunya rekonstruksi atas pengetahuan Islam agar kondusif dengan kehidupan modern yang merupakan ranah pengembangan kehidupan manusia. Gus Dur menyatakan bahwa warisan Islam pada masa lalu haris disusun kembali dalam teks yang baru yang sesuai dengan konteks, karena perkembangan dalam kehidupan manusia harus juga diikuti perkembangan dalam hukum Islam. Islam dapat mendefinisikan prioritasnya apabila Islam mampu memadukan hukum atas berbagai peristiwa dengan sifat tujuan ilmiah (ilmu pengetahuan). Menurut Gus Dur hanya dengan memberikan konsesnsi tersebutlah Islam dapat mendefinisikan kembali prioritasnya, merumuskan pandangan dunia, dan merestruksikan ajaran sebagai suatu proses yang diperlukan untuk menempatkan Islam dalam arus utama pembangunan manusia. ${ }^{47}$

Penjelasan diatas menggambarkan berbagai konsekuensi dari penempatan ajaran Islam di dalam pengembangan kehidupan manusia yang dibawa oleh proses modernisasi. Saran Gus Dur untuk melakukan rekonstruksi Islam dalam kerangka pengembangan kemanusiaan ini merupakan syarat metodologis dari humanisme atau kosmopolitanisme Islam. Di satu sisi humanisme membutuhkan perluasan pengetahuan Islam sehingga menjadi Islam kosmopolitan. Disisi lain untuk mencapai kosmopolitan, Islam harus direkonstruksi ajarannya, di formulasi pandangan dunianya, serta diredifinisi priporitas perjuangannya. 48

Untuk memudahkan pemahaman kepada pembaca, penulis merumuskan konsep humanisme Gus Duryang dapat dipahami melalui dasar ontologis, dimana dasar ini mencakup kesatuan pemikran Islam. Menurut Gus Dur dalam Islam terdapat tiga realitas yakni realitas universal, realitas kosmopolitan dan realitas kultural. Gus Dur memahami Islam dalam tiga gagasan yang menjadi pijakan dan muara normatif dari keislamannya yakni universalisme Islam, kosmopolitanisme Islam, dan Pribumisasi Islam (Gambar 1).

45 Abdurrahman Wahid, Pergulatan Negara, Agama dan Kebudayaan, p. 188.

46 Syaiful Arif, Humanisme Gusdur: Pergumulan Islam dan Kemanusiaan, p. 292.

47 Abdurrahman Wahid, Islam The State, and Development in Indonesia, dalam makalah dialog nasional bersama Dr. Mochtar Buchori di LIPI, 1980-1981, 63.

48 Syaiful Arif, Humanisme Gusdur: Pergumulan Islam dan Kemanusiaan, p. 299. 

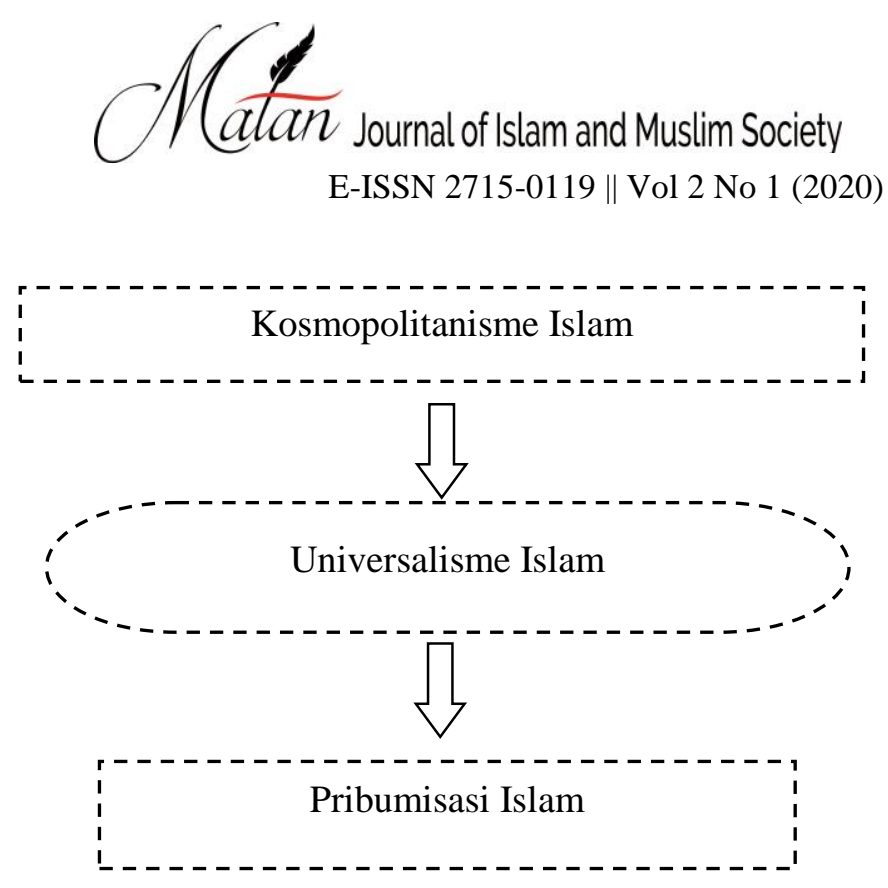

Gambar 1 Muara normatif dari keislaman Gus Dur

Dari bagan diatas terlihat bahwa pusat yang menaikkan Islam ke ranah kosmopolitan adalah universalisme Islam, sekaligus menurunkan Islam ke ranah budaya lokal dalam kerangka pribumisasi Islam. ${ }^{49}$ Proses menaik menggambarkan naiknya Islam ke ranah global. Serta proses turun menggambarkan menurunnya Islam ke ranah lokal. Semua proses ini berporos pada universalisme Islam, ${ }^{50}$ dan sekaligus kembali kepada titik universal tersebut. Pada titik inilah humanisme terpatri, yakni di dalam universalisme Islam dan dalam mewujudkan universalisme tersebut dapat di peroleh baik melalui kosmopolitanisme ${ }^{51}$ maupun pribumisasi Islam. ${ }^{52}$

Sementara itu runutan nilai yang menjadi prinsip-prinsip dasar dari humanisme Gus Dur dapat dilihat dari Gambar 2:

${ }^{49}$ Pribumisasi Islam merupakan pembacaan Gus Dus akan mekanisme Islamisasi Nusantara yang membentuk corak khas keislaman Nusantara. Pribumisasi Islamadalah upaya kontekstualisasi Islam kedalam realitas masyarakat dengan memanfaatkan metode pengambilan hukum yang disediakan oleh ushul fiqh dan qawa 'id al-fiqhiyyah. Dengan demikian pribumisasi Islamnerupakan pertemuan Islam dengan budaya lokal. Selain bermakna antropologis yang menempatkan budaya kedalam artefak sejarah, adat, tradisi, dan kesenian masyarakat lokal. Syaiful Arif, Humanisme Gusdur: Pergumulan Islam dan Kemanusiaan, p. 300.

${ }^{50}$ Universalisme Islam merupakan nilai-nilai yang paling universal dalam Islam yang merujuk pada kepedulian Islam atas nasib kemanusiaan. Manifestasinya terdapat pada jaminan atas hak-hak dasar manusia, dan menjadi tujuan etis bagi perumusan syariat Islam. Syaiful Arif, Humanisme Gusdur: Pergumulan Islam dan Kemanusiaan, p. 299.

${ }^{51}$ Kosmopolitanisme merupakan keseimbangan antara ketaatan normatif dalam mematuhi ajaran agama Islam, dengan kebebasan berfikir dari umat Islam. Kebebasan berfikir ini yang akhirnya meluaskan wawasan Islam sehingga bertemu dengan pengetahuan Yunani apada awal Islam serta peradaban Eropa di amsa modern Islam. Tanpa kosmopolitanisme nilai-nilai universalisme Islam hanya akan menjadi kerangka teoritik dan bahkan moralistik yang tidak dapat diterapkan di dalam realitas komtemporer masyarakat modern. Lihat Syaiful Arif, Humanisme Gusdur: Pergumulan Islam dan Kemanusiaan, p. 298.

${ }^{52}$ Syaiful Arif, Humanisme Gusdur: Pergumulan Islam dan Kemanusiaan, p. 303. 

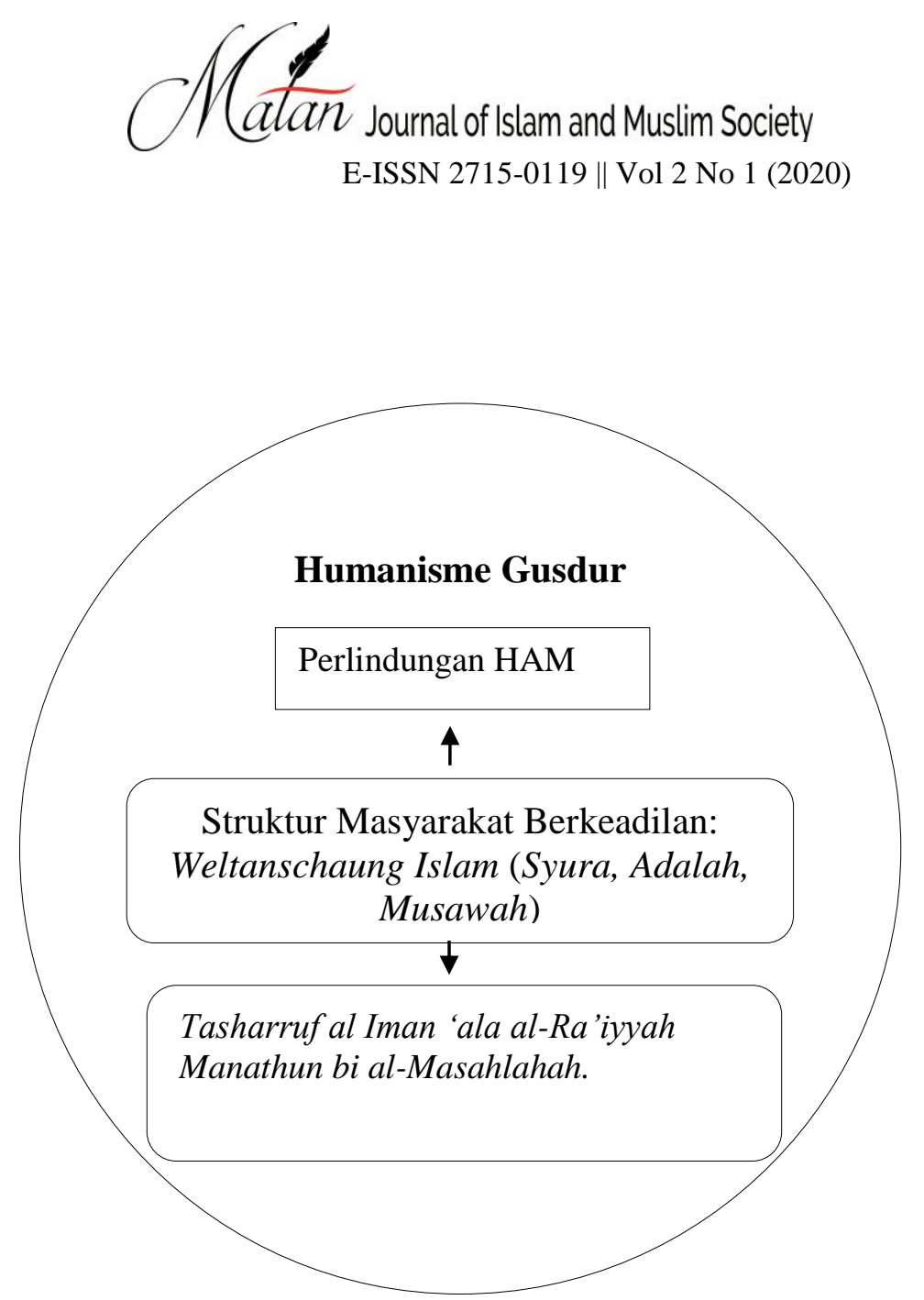

Gambar 2 Prinsip-prinsip dasar dari humanisme Gus Dur

Bagan di atas menggambarkan konsep dasar humanisme Gus Dur. Konsep humanisme berasal dari prinsip dasar Gus Dur sendiri, yakni perlindungan atas HAM dan pengembangan struktur masyarakat berkeadilan. Maka jaminan atas lima hak dasar manusia (kulliyat alkhams) dalam muqashid al-syariah merupakan materi HAM yang harus dilindungi. Jaminan atas hak-hak dasar manusia ini oleh Gus Dur ditempatkan sebagai nilai-nilai universal di dalam Islam. Dengan demikian, kemanusiaan ditempatkan sebagai universalisme Islam. Universalisme Islam dalam konteksini menempatkan tiga nilai kemasyarakatan, yakni syura, 'adalah, dan musawah sebagai nilai-nilai dasar yang menjadi pandangan dunia Islam. Artinya demokrasi, keadilan sosial, dan supremasi hukum harus menjadi paradigma berpikir umat Islam, yang menjadi dasar segenap produk pemikirannya. ${ }^{53}$

Pandangan dunia Islam inilah yang diprakarsai dengan menempatkan kesejahteraan rakyat sebagai nilai praksis utama yang merangkum segenap nilai humanisme Gus Dur. Pada titik inilah humanismenya disebutsebagai "humanisme sosial". Sebab kemanusiaan diprakarsai dalam bentuk kesejahteraan rakyat. Corak humanisme sosial ini terlihat dalam Gambar 3.

53 Syaiful Arif, Humanisme Gusdur: Pergumulan Islam dan Kemanusiaan, p. 307. 

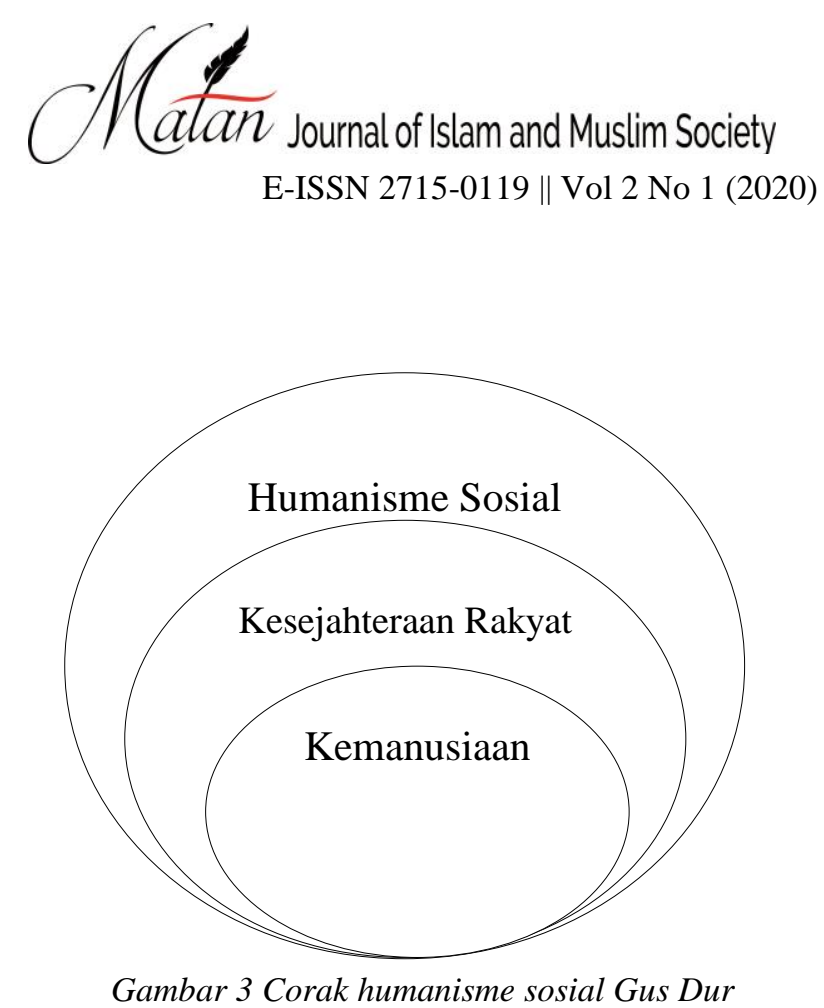

Artinya kemanusiaan yang diwacanakan dalam humanisme Gus Dur bukan kemanusiaan Abstrak, melainkan bersifat praksis dengan merujuk pada kesejahteraan rakyat. Hal ini senada dengan nilai humanisme yang ada di dalam pancasila, yang mempraksiskan sila Kemanusiaan yang Adil dan Beradab ke dalam sila Keadilan Sosial Bagi Seluruh Rakyat Indonesia. Dari humanisme ini kemudian Gus Dur mengkritik kondisi struktural yang mengahalangi kesejahteraan rakyat. Maka humanisme sosial adalah pengembangan struktur masyarakat yang adil dan merupakan konsekuensi logis dari perjuangan pemenuhan hak-hak dasar manusia. ${ }^{54}$ Selain itu, dalam konteks ini Gus Dur menempatkan negara sebagai alat penyejahtera rakyat. Dengan posisi sebagai alat kesejahteraan ini, bentuk negara tidak harus Islami, tetapi negara tersebut harus mampu ajran Islam sebagai nilai utama sebagai alat kesejahteraan. ${ }^{55}$

\section{Simpulan}

Humanisme dalam pemikiran Gus Dur merupakan pembahasan yang menarik karena menyediakan diskursus humanisme dalam perspektif Islam. Letak humanisme yang digagas Gus Dur ini yang paling penting adalah posisinya yang tidak bertentangan dengan agama, tidak seperti humanisme modern yang lahir dari sekulerisasi Eropa. Perjuangannya untuk memuliakan harkat manusia dipahami sebagai pelaksaan perintah Tuhan. Humanisme Gus Dur berangkat dari asumsi keagamaan yang menempatkan manusia sebagai makhluk terbaik ciptaan Tuhan. Dengan posisi sebagai khalifatullah fi al-ard, manusia memiliki kebebasan untuk memenuhi potensi manusiawinya. Humanisme menjadi prespektif yang penting untuk dibicarakan, karena untuk melihat produk pemikiran Gus Dur yang pemikirannya tidak secara langsung menyebutkan humanisme.

Gus Dur telah memprakarsai kesinambungan antara Islam, Kemanusiaan dan

${ }^{54}$ Syaiful Arif, Humanisme Gusdur: Pergumulan Islam dan Kemanusiaan, p. 309.

${ }^{55}$ Menurut Abdurrahman Wahid Islam haruslah ditilik dari fungsinya sebagai pandangan hidup yang mementingkan kesejahteran warga masyarakat. Dalam membicarakan persoalan bentuk negara dan sistem pemerintah ia berpedoman pada pendekatan fikih Imam Syafi'I, Abdurahman Wahid membedakan bentuk negara dalam tiga tipologi, dar al-Islam (negara Islam), dar al-Harb (negara perang atau anti Islam), dan dar al-Sulh (negara damai). Lihat Ahmad Salehudin, Abdurrahman Wahid: Keislaman, Kemanusiaan, dan Kebangsaan, p. 141. 
kebudayaan di ranah kebangsaan. Melalui kebangsaan kesejahteraan manusia berusaha diwujudkan melalui bangunan negara-bangsa. Komitmen atas kesejahteraan rakyat merupakan komitmen Gus Dur atas kemanusiaan, dengan komitmen dan landasan keagamaan inilah ia meluaskan pemikiran dan perjuangannya dalam proses pemanusiaan kehidupan.

\section{Daftar Pustaka}

Ahmed, Akbar S. 1990. Membedah Islam, terj. Zulfahmi Andri, Bandung: Pustaka.

Arif, Syaiful. 2013. Humanisme Gusdur: Pergumulan Islam dan Kemanusiaan, Yogyakarta: Ar-Ruzz Media.

Aristoteles. 2004. Nicomachean Ethics, Sebuah Kitab Suci Etika, Terj. Embun Kenyowati, Jakarta: Teraju.

Bartolomeus, Sambho. 2013. Humanisme dan Humaniora, ed. Bambang Sugiharto, Bandung: Matahari.

Barton, Greg. 1999. Gagasan Islam Liberal di Indonesia: Pemikiran Neo-Modernisme Nurcholish Madjid, Djohan Effendim Ahmad Wahid dan Abdurrahman Wahid, Jakarta: Paramadina-Pustaka Antara. . 2008. Biografi Gus Dur, terj. Lie Hua, cetakan ke-VII,(Yogyakarta: LKiS.

Davies, Tony. 1997. Humanism, New York: Roudledge.

Hadi, Samasno. 2012. Konsep Humanisme Yunani Kuno dan Perkembangannya Dalam Sejarah Pemikiran Filsafat, dalam Jurnal Filsafat, Volume 2, Nomor 2.

Hadiwoyono, Harun. 1995. Sari Sejarah Filsafat Barat 2, Yogyakarta: Kanisius.

K.H. Darwis, Ellyasa, 1994. Gus Dur dan Masyarakat Sipil, Yogyakarata: LkiS.

Kurzman, Charles. 2003. Wacana Islam Liberal Memikikan Islam Kontemporer Tentang Isu-isu Global, terj. Bahrul Ulum dan Heri Junaidi, Jakarta: Paramadina.

Latif, Yudi. 2011. Negara Paripurna, Historisitas, Rasionalita dan Aktualisasi Pancasila, Jakarta: Gramedia.

Masdar, Umaradi. 1998. Membaca Pikiran Gusdur dan Amien Rais Tentang Demokrasi, Yogyakarta: Pustaka Pelajar.

Muhammad, Alvian dan Helmi Jacob (ed). 2005. Gus Dur Bertutur, Jakarta: Divisi Penerbit Harian Proaksi.

Mulyana. 2016. Humanisme dan Tantangan Kehidupan Beragama, dalam Jurnal Agama dan Lintas Budaya, Volume 1, Nomor 1.

Salehudin, Ahmad. 2019. Abdurrahman Wahid: Keislaman, Kemanusiaan dan Kebangsaan, Yogyakarta: Basabasi.

Tim INCRes. 2000. Beyond The Symbols: Jejak Antropologis Pemikiran dan Gerakan Gus Dur, Bandung: Remaja Rosdakarya.

Wahid, Abdurrahman. 1980-1981. Islam The State, and Development in Indonesia, dalam makalah dialog nasional bersama Dr. Mochtar Buchori di LIPI. 


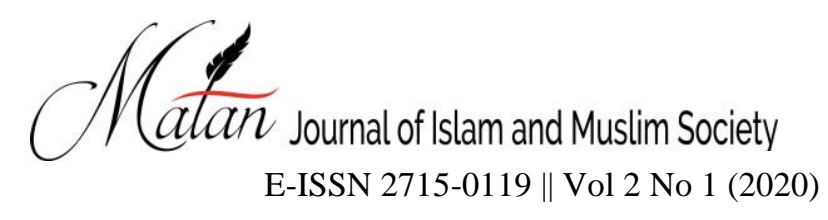

1998. Dialog Agama dan Masalah Pendangkalan Agama, dalam Komaruddin Hidayat dan Ahmad Gaus, Jakarta: Gramedia Pustaka Utama.

. 2001. Pergulatan Negara, Agama dan Kebudayaan, Depok: Desantara.

. 1988. Universalisme Islam dan Kosmopolitan Peradaban Islam, pelita.

. 2006. Islamku, Islam Anda, Islam Kita: Agama Masyarakat Negara Demokrasi, Jakarta: the Wahid Institut.

2010. Prisma Pemikiran Gus Dur, Yogyakarta: LkiS.

Yahya, Ali. 2007. Sama tapi Berbeda, Potret Keluarga Besar KH. Wahid Hasyim, (Jombang: Pustaka Ikapete the Ahmadi Institut. 